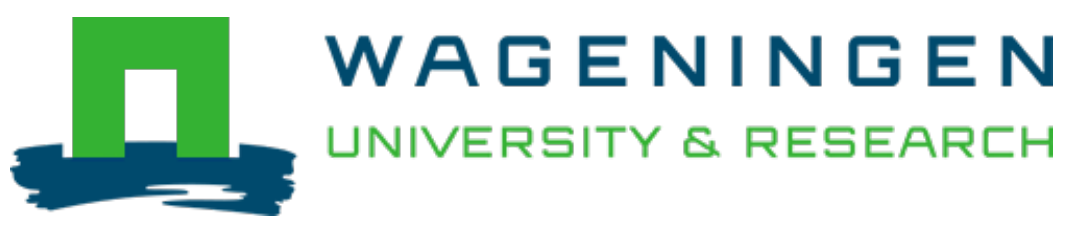

\title{
The Internal Market, Incomplete: EU, Dutch and Belgian Legislation on Maximum Food Fortification with Micronutrients
}

\author{
European Food and Feed Law Review \\ Meer, Lisa; Schebesta, H. \\ https://effl.lexxion.eu/article/EFFL/2020/3/5
}

This article is made publicly available in the institutional repository of Wageningen University and Research, under the terms of article $25 \mathrm{fa}$ of the Dutch Copyright Act, also known as the Amendment Taverne. This has been done with explicit consent by the author.

Article 25 fa states that the author of a short scientific work funded either wholly or partially by Dutch public funds is entitled to make that work publicly available for no consideration following a reasonable period of time after the work was first published, provided that clear reference is made to the source of the first publication of the work.

This publication is distributed under The Association of Universities in the Netherlands (VSNU) 'Article $25 \mathrm{fa}$ implementation' project. In this project research outputs of researchers employed by Dutch Universities that comply with the legal requirements of Article $25 \mathrm{fa}$ of the Dutch Copyright Act are distributed online and free of cost or other barriers in institutional repositories. Research outputs are distributed six months after their first online publication in the original published version and with proper attribution to the source of the original publication.

You are permitted to download and use the publication for personal purposes. All rights remain with the author(s) and / or copyright owner(s) of this work. Any use of the publication or parts of it other than authorised under article $25 \mathrm{fa}$ of the Dutch Copyright act is prohibited. Wageningen University \& Research and the author(s) of this publication shall not be held responsible or liable for any damages resulting from your (re)use of this publication.

For questions regarding the public availability of this article please contact openscience.library@wur.nl 


\title{
The Internal Market, Incomplete: EU, Dutch and Belgian Legislation on Maximum Food Fortification with Micronutrients
}

\author{
Lisa N. van der Meer and Hanna Schebesta*
}

The article shows that food fortification legislation at the EU level leaves the achievement of the internal market incomplete. Regulation (EC) No 1925/2006 on the addition of vitamins, minerals and certain other substances to foods regulates the addition of micronutrients to food. A regulatory check of two markets in the European Union (EU) shows that EU countries at national level take diverging approaches to food fortification. In the Netherlands, food fortification with vitamin A (in the form of retinoid), selenium, copper and zinc is prohibited if it concerns food fortification in the strict sense. This regime is subject to an exemption authorisation scheme. The main reason why food fortification with some substances is not allowed in the Netherlands is because the range between the Recommended Daily Average (RDA) and the maximum Tolerable Upper Intake Level (UL) is too small. A safe level of intake would then not be much higher than the RDA. In this article, the different ranges between the RDA's and the UL in the Netherlands, Belgium and the EU have been compared. Following the results of this report, these ranges do not seem to differ substantially and therefore, a priori do not seem to be a convincing scientific argument for divergent legislation on whether or not to prohibit food fortification with specific micronutrients. The results are discussed in light of EU regulation of on the addition of vitamins and minerals and the free movement of goods.

\section{Introduction}

Consumers are increasingly concerned about their health and pay more attention to their lifestyle and the healthiness of their diet. ${ }^{1}$ The growing consumer interest in health has driven the development of foods that offer specific beneficial effects. ${ }^{2}$ Such beneficial effects on the body can derive from both, compounds that are added industrially or functional molecules that are naturally present in foods. ${ }^{3}$ One of the substances that can be added to food are micronutrients, of which vitamins and minerals are the best known group; they are essential for growth and for the maintenance of a healthy body. ${ }^{4}$ However, vitamins and minerals can also have potentially harmful effects when consumed in excess. A chronic high intake of zinc, for instance, interferes with the intake of copper, which can result in neurological diseases. ${ }^{5}$ This is why tolerable upper intake levels (UL's) are scientifically established, which are defined as "the maximum level of total chronic daily intake of a nutrient (from all sources) judged to be unlikely to pose a risk of adverse health effects to humans". 6

\footnotetext{
Hanna Schebesta is Associate Professor in the LAW group at Wageningen University (WUR, the Netherlands) and was previously a Research Associate at the European University Institute (EUI, Italy). Lisa van der Meer is a Projectmanager verpakkingen bij Cérélia Netherlands B.V.

1 Szakály Z., Szente V., Kövér G., Polereczki Z. and Szigeti O., "The influence of lifestyle on health behavior and preference for functional foods" 58(1) Appetite (2012), pp. 406 et sqq.

2 Granado-Lorencio, F., and Hernandez-Alvarez, E., "Functional foods and health effects: a nutritional biochemistry perspective", 23(26) Current Medicinal Chemistry (2016), pp. 2929 et sqq.
}

3 Katan M.B. and De Roos N.M., "Promises and problems of functional foods", 44 Crit. Rev. Food Sci. (2004) pp. 369 et sqq.

4 Das, J. K. et al., "Food fortification with multiple micronutrients: impact on health outcomes in general population", 12 Cochrane Database of Systematic Reviews (2019).

5 EFSA NDA Panel (EFSA Panel on Dietetic Products, Nutrition and Allergies), "Scientific opinion on dietary reference values for zinc" 12(10) EFSA Journal (2014) at p. 76.

6 European Commission Health and Consumer Protection Directorate-General, Discussion paper on the setting of maximum and minimum amounts for vitamins and minerals in foodstuffs, (2006) Brussels, Belgium. 
From a food technological point of view, distinct reasons for adding vitamins, minerals and other substances to food exist, namely (a) reconstitution, (b) substitution, and (c) food fortification in the strict sense. These distinct purposes are usually also reflected in regulatory frameworks. Firstly, there is (a) the process of reconstitution: where foodstuffs lose original properties through processing, the addition of micronutrients is allowed in order to nutritionally reconstruct the original properties. This serves to ensure that the product continues to have the nutritional characteristics that the consumer would expect from the original. (b) Where products are a clear substitute for other products, the addition of micronutrients can be an attempt to safeguard the overall nutritional diet. The most famous example is margarine; since it lacks the Vitamin A and D present in butter, which it replaces, the addition of vitamins and minerals enables consumers to switch to margarine without losing the nutritional benefits of butter. (c) The last technological purpose is food fortification in the strict sense. This is the addition of substances to foodstuffs in order to achieve food supplementation. From an intake perspective, this is also the only case where additions to food would factually alter the overall nutrition intake of consumers. For these reasons, the last process is the most contentious, and for instance in the Netherlands, it is only food fortification in the strict sense that is very restricted.

Since 2006, Regulation (EC) No 1925/2006 governs the addition of vitamins and minerals and of certain other substances to foods. ${ }^{7}$ The introduction of this law was justified by the fact that Member States had differing rules on the addition of vitamins and minerals, thus impeding the functioning of the internal market. This concerned both, legislation that made fortification of certain foodstuffs mandatory, as well as national legislation prohibiting or restricting fortification to certain maximum amounts. While Reg-

7 Commission Regulation (EC) No 1925/2006 on the addition of vitamins and minerals and of certain other substances to foods, OJ 2006 L 404/26. For a discussion of the overall framework, see Kireeva, I. and O'Connor, B., "Food Alone is Not Enough? A Legal Overview of the Fortification Regulation of the European Union", European Food and Feed Law Review 6(2) (2011), pp. 104 et seq.; Hagenmeyer, M. and Loosen, P., "Fortification for Everyone?" European Food and Feed Law Review, 2(4) (2007), pp. 189 et seq.

8 Ibid, Article 3, Annex 1.

9 Koninklijk Besluit van 3 Maart 1992 betreffende het in de handel brengen van nutriënten en van voedingsmiddelen waaraan nutriënten werden toegevoegd (B.S. 15.IV.1992), 1992. ulation 1925/2006 intended to harmonize food fortification, the European Commission, contrary to what was foreseen at the time, never proceeded to set the maximum and minimum amounts. The EU legal framework is discussed in Section II.

The legislative standstill was justified by the fact that scientific uncertainty persisted with respect to the harm caused by vitamins, minerals, and other substances. Perhaps the European Commission wanted to wait some time to see how the new piece of legislation would perform in the Member States. Now, almost 15 years after its adoption, there seems to be a good case for revisiting the Regulation, specifically to evaluate how it performs in practice.

Currently, Member States continue to have national legislation on food fortification; the article examines the legal frameworks and the scientific basis in the Netherlands (Section III) and Belgium (Section IV). One of the Member States that has adopted a restrictive approach to the addition of certain micronutrients is the Netherlands, which we use as a national case study in this article and contrast with Belgium. For instance, Regulation 1925/2006 allows to add vitamin A (in the form of retinoid), selenium, copper and zinc to food (which shall not exceed a maximum amount) within the EU. ${ }^{8}$ However, the Netherlands only allows the addition of vitamin A (in the form of retinoid), selenium, copper and zinc to a reconstituted foodstuff or a substitution product. Since 1992, Belgium has allowed the addition of vitamin A (in the form of retinoid), selenium, copper and zinc to food within certain limits. ${ }^{9}$ In this article, we use these substances as examples for the discussion. Our comparison (Section V) of the Dutch fortification legislation with that of its neighbour, Belgium, shows that national legislation differs a lot even where population and geography are relatively similar. The changes in the available scientific nutrition values and methodologies are discussed for the Netherlands, Belgium and the EU.

Based on the analysis we conclude (Section VI) with a discussion on the findings and recommendations for future EU legislation.

\section{EU Regulation of Food Fortification}

\section{EU Legal Framework}

In December 2006, Regulation (EC) No 1925/2006 on the addition of vitamins and minerals and of certain 
other substances to foods came into force. ${ }^{10}$ The legal diversity of how Member States regulated food fortification created unequal conditions of competition and impeded the free movement of these products. The Regulation's objective was to harmonize these differing national provisions, whilst also providing a high level of consumer protection.

Art. 3 (1) Regulation (EC) No 1925/2006 states that only vitamins and/or minerals listed in Annex I, in the forms provided in Annex II, may be added to foods. Annex I contains a list of vitamins and minerals that may be added to foods, and Annex II the vitamin formulations and mineral substances. Art. 6 states that when a vitamin or mineral is added to foods, the total amount of the vitamin or mineral present, for whatever purpose, in the food as sold shall not exceed maximum amounts. These maximum amounts shall be set by taking into account (a) the upper safe levels of vitamins and minerals established by scientific risk assessment based on generally acceptable scientific data, and varying degrees of sensitivity of different groups of consumers. ${ }^{11}$ In addition, (b) the intakes of vitamins and minerals from other dietary sources must be taken into account. ${ }^{12}$ Reference should further be made to the reference intakes of vitamins and minerals of the population. ${ }^{13}$ In case the reference intakes are close to the upper safe levels, the contribution of an individual product to the overall diet and the nutrient profile of a product should be taken into account. ${ }^{14}$ While the maximum amounts were not set, the parameters for establishing maximum amounts were already defined.

The Regulation foresaw that the European Commission could submit a draft measure to set these maximum amounts. The European Commission opened a consultation in $2006^{15}$, and in 2007 published an orientation paper ${ }^{16}$ based on the responses received. More than ten years later, the maximum amounts for vitamins and minerals in the EU have not been set.

\section{Case Law on the Maximum Amounts for Vitamins and Minerals of the Court of Justice of the EU}

In the absence of EU harmonisation, Member States retain the possibility to continue to regulate food fortification at national level. Since the 1980s, several cases about food fortification and supplementation have reached the Court of Justice. Pending the finalisation of the EU harmonisation on this matter, this case law remains pertinent in important respects.

Two cases challenging the Dutch authorisation system for food fortification and supplementation date from the 8os. In both judgments, the Court underlined the importance of scientific uncertainty with respect to establishing the possibility of Member States to rely on the public health justifications. For the addition of vitamins and minerals, the uncertainties particularly related to "the critical quantities and the precise effects" (the Sandoz case about Muesli bars with vitamins). ${ }^{17}$ The absence of scientific knowledge was also confirmed in van Bennekom ${ }^{18}$ although the Court acknowledged the risks: "the excessive consumption of vitamins over a prolonged period may have harmful effects, the extent of which varies according to the type of vitamin, there being generally a greater risk with vitamins soluble in fat than with those soluble in water. It is further apparent that it is principally in high concentrations that vitamins constitute a serious risk to health" ${ }^{19}$

In the absence of scientific certainty, a national authorisation system prohibiting the marketing of vitamin-enriched foodstuffs without authorisation, even if lawfully marketed in another member state, complies with EU law. However, under EU law, such authorisation system would not be allowed to require proof by the importer that the product is not harmful to health, ${ }^{20}$ only that the importer submit any in-

\footnotetext{
10 Commission Regulation (EC) No 1925/2006, supra note 7.

11 Ibid, Article 6(3)(a)

12 Ibid, Article 6(3)(b).

13 Ibid, Article 6(4).

14 Ibid, Article 6(5).

15 European Commission Health and Consumer Protection Directorate-General, Discussion paper on the setting of maximum and minimum amounts for vitamins and minerals in foodstuffs, (2006) Brussels, Belgium.

16 European Commission Health and Consumer Protection Directorate-General, Orientation Paper on setting maximum and minimum amounts for vitamins and minerals in foodstuffs, Brussels, SANCO/E4/FDA/bs(2007)D/540510, available at http://liberterre.fr/liberterres/codex/z-pdf-codex/ec_paper_july2007.pdf.

17 Case C-174/82, Officier Van Justitie v Sandoz [1983] ECR 2445, at para. 11 .

18 Case C-227/82, Van Bennekom [1983] ECR 3883, at para. 36.

19 Ibid.

20 Sandoz, supra note 17 , at para. 24.
} 
formation in its possession to allow the authorities to make such an assessment.

The Dutch system was again questioned in Court in a judgment of $2004^{21}$ concerning breakfast cereals fortified with Vitamin D and folic acid and energy bars fortified with folic acid. ${ }^{22}$ The fortified products had been refused market authorisation, whereas those products were already lawfully marketed in other Member States. The Netherlands seemingly had not considered the role of breakfast cereals as a substitution product. Until 1999, fat spreads had to be fortified with Vitamin D by law, and the Court held that a public health-based risk assessment would have needed to take substitution mechanisms into account. ${ }^{23}$ In addition, the Netherlands made the existence of an actual nutritional need a precondition for the granting of a derogation. While this criterion could play a role in the risk assessment, by itself, it would not be sufficient to justify a restriction to the free movement of goods under (then) Article $36 .^{24}$

Similar cases had arisen against Denmark ${ }^{25}$ and Norway, ${ }^{26}$ Austria ${ }^{27}$ and Germany. ${ }^{28}$ In these cases, the CJEU held that national systems violated EU law due to over-generalizations of marketing bans, for instance for failing to distinguish "according to the different vitamins and minerals added or according to the level of risk which their addition may possibly pose to public health". ${ }^{29}$ Similarly, in the French case

21 Case C-41/02, Commission v Netherlands [2004] ECR I-11375.

22 Kugel, P. J. "Admissibility of Fortified Foods and Drinks in the Netherlands." European Food and Feed Law Review 1(2) (2006), pp. 93 et seq.

23 Commission $v$ Netherlands, supra note 21, at para. 66.

24 Ibid, at para. 70.

25 Case C-192/01, Commission v Denmark [2003] ECR I-09693 (the Court declared that "by applying an administrative practice which entails that enriched foodstuffs lawfully produced or marketed in other Member States can be marketed in Denmark only if it is shown that such enrichment with nutrients meets a need in the Danish population, the Kingdom of Denmark has failed to fulfil its obligations under Article 28 EC" (at para. 57). The Court explained that this practice "does not enable Community law to be observed in regard to the identification and assessment of a real risk to public health, which requires a detailed assessment, case-by-case, of the effects which the addition of the minerals and vitamins in question could entail" (at para. 56)).

26 Case E-3/00, EFTA Surveillance Authority v Norway (EFTA Court Report 2000/01, p. 73) (the EFTA Court held that "by applying its legislation so as to prohibit the import and marketing in Norway of corn flakes, fortified per $100 \mathrm{~g}$ with $1 \mathrm{mg}$ thiamine, $1 \mathrm{mg}$ riboflavin, $10 \mathrm{mg}$ niacin and $7 \mathrm{mg}$ iron, which have been lawfully manufactured and marketed in other EEA States, the Kingdom of Norway had, at the relevant time, i.e. 14 January 2000, failed to

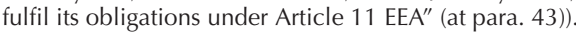

of enriched confectionery and drinks, ${ }^{30}$ a general prohibition to add vitamins and minerals was too vague, as it failed to specify the specific risks of vitamins and minerals. In other words, a blanket prohibition of the addition of vitamins and minerals to foodstuffs violates EU law. ${ }^{31}$

The Court further enumerated a number of principles that authorisation systems have to respect. Generally, the Court requires a case-by-case risk assessment. The case Greenham and Abel ${ }^{32}$ concerned a juice with coenzyme Q10 and vitamins. Here the CJEU specified additional preconditions for authorisation, such as accessibility of the procedure and reasonableness of time.

If scientific uncertainty about the potential harms of specific vitamins and minerals persisted, the precautionary principle would be pertinent in allowing national regulation. In line with this, the Court also stated that if it is impossible "to determine with certainty the existence or extent of the alleged risk because of the insufficiency, inconclusiveness or imprecision of the results of studies conducted, but the likelihood of real harm to public health persists should the risk materialise, the precautionary principle justifies the adoption of restrictive measures". ${ }^{33}$ This large margin of appreciation has been confirmed in the recent case law: in case of scientific uncertainty about the harmful effects for health of certain substances, "the margin of discretion of Member States

27 Case C-150/00, Commission v Austria [2004] ECR I-03887 (the Court declared that "by systematically classifying as medicinal products vitamin preparations and preparations containing minerals lawfully manufactured or marketed as food supplements in other Member States where they contain either more vitamins other than vitamins A, C, D or K, or more minerals other than those in the chromate group, than the simple daily amount of those nutritive substances, or vitamins A, D or K, irrespective of their content, the Republic of Austria has failed to fulfil its obligations under Article 28 EC" (at para. 102)).

28 Case C-387/99, Commission v Germany [2004] ECR I-03751 (the Court declared that "by automatically classifying as medicinal products vitamin preparations lawfully manufactured or marketed as food supplements in the other Member States where they contain three times more vitamins, other than vitamins $A$ and $D$, than the daily amount recommended by the German Food Association, the Federal Republic of Germany has failed to fulfil its obligations under Article 30 of the Treaty" (at para. 83)).

29 Commission v Denmark, at para. 55.

30

31 Ibid.

32 Case C-95/01, Greenham and Abel [2004] ECR I-01333.

33 Commission v Denmark, supra note 25, at para. 52; also Greenham and Abel, supra note 32, at para. 48 . 


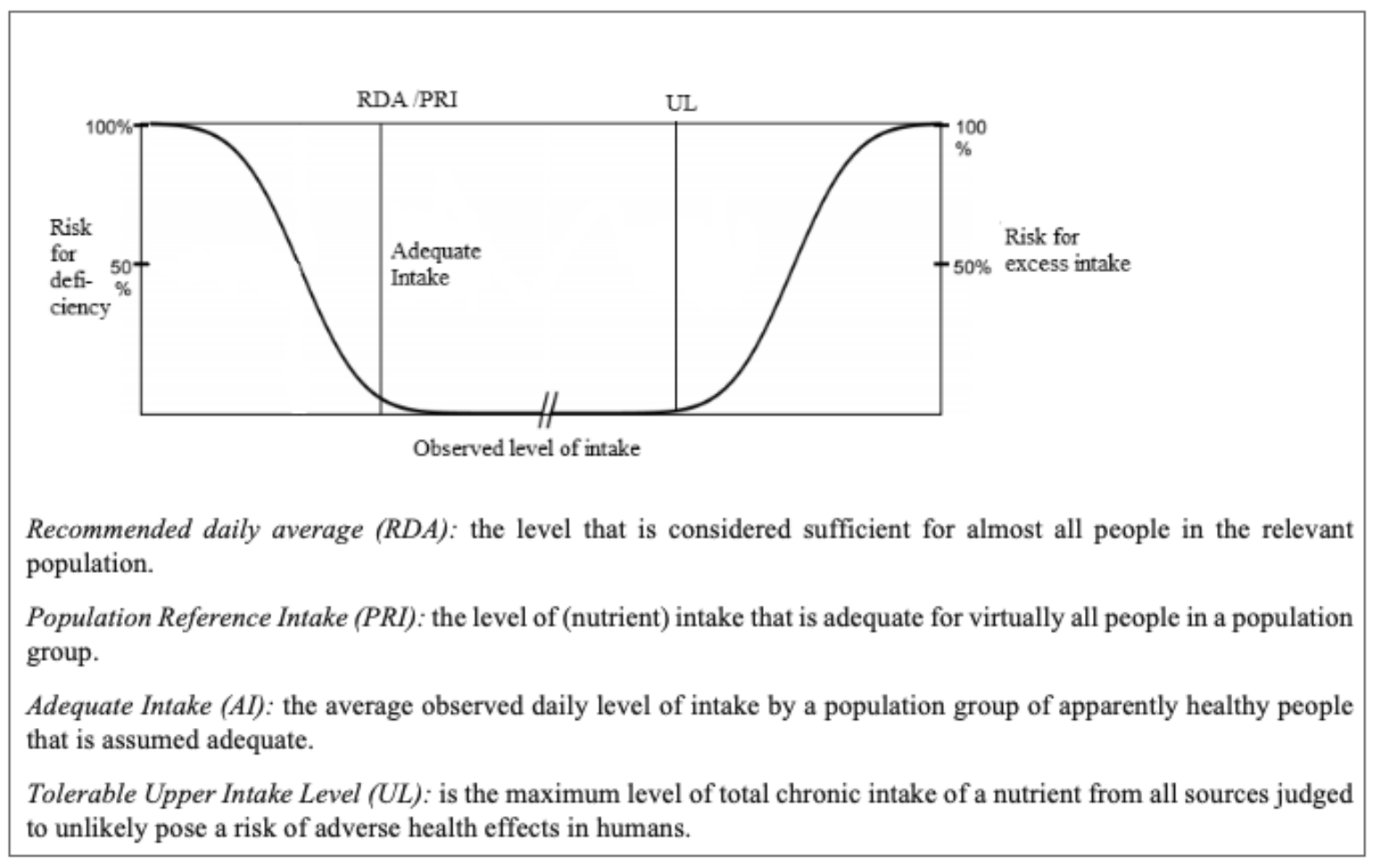

Figure 1: The Different Nutritional Standards

relating to the choice of the level at which they intend to guarantee the protection of public health is particularly large". ${ }^{34}$

Also, in analogy to recent case law in the field of supplements, it is abundantly clear that as long as the Commission fails to lay down the maximum amounts of nutrients, the Member States remain competent to adopt legislation relating to those amounts. $^{35}$

\section{Establishing Scientific Data}

In light of the importance that is accorded to 'scientific uncertainty' in justifying national approaches under EU law, it is important to look at the available data. The regulation of the addition of micronutrients to foodstuffs seeks to establish a precarious balance between encouraging a minimum intake for the population while preventing harmful excess intake. The (non-)availability of the necessary scientific data is a serious challenge. According to the Regulation, maximum fortification levels for vitamins and minerals should be set by taking into account upper safety levels (ULs), an intake estimation that takes into account different dietary sources, as well as recommended or reference intake values for the population.

A lot of work on nutritional values has been completed since the inception of the Regulation. The most advanced assessment had been done on the Tolerable Upper Intake Levels (ULs), that are maximum level of "total chronic intake of a nutrient from all sources judged to be unlikely to pose a risk of adverse health effects in humans". ${ }^{36}$ Originally, the European Food Safety Authority (EFSA) and the Scientific Committee on Food provided a scientific opinion and published a report to establish ULs on 16 of the nu-

34 Case C-282/15, Queisser Pharma, ECLI:EU:C:2017:26, at para. 63; Case C-446/08, Solgar Vitamin's France and Others [2010] ECR I-03973, paras. 35 and 36.

35 Case C-672/15, Noria Distribution, ECLI:EU:C:2017:310, at para. 16; Solgar Vitamin's France and Others, supra note 34, at para. 24

36 EFSA, Overview on Tolerable Upper Intake Levels as derived by the Scientific Committee on Food (SCF) and the EFSA Panel on Dietetic Products, Nutrition and Allergies (NDA), (September 2018), at p. 1. Available at https://www.efsa.europa.eu/sites/default/files/assets/UL_Summary_tables.pdf. 
trients listed in 2006. ${ }^{37}$ The European Commission requested EFSA to update these values and extend the substances covered, a work that was concluded by EFSA in 2018 for vitamins and minerals. ${ }^{38}$

The second scientific base to establish maximum amounts for food fortification, namely their intake from various dietary sources, proved much harder to establish, and in 2007 EFSA was only at a preliminary stage. ${ }^{39}$ This is the area where the data gap was the most severe. Lastly, the Regulation states that the recommended or reference intake should be taken in to account. These are 'normative' values trying to establish amounts that ensure that no deficiencies occur for the general population. Based on older science, in the 1990s, the Nutrition Labelling Directive already set RDAs. ${ }^{40}$ Later, Regulation (EC) No 1169/2011 on food information to consumers set a daily reference intake (RI) for vitamins and minerals (adults). ${ }^{41}$ In 2017, EFSA concluded its work on Dietary Reference Values (DRV), an umbrella term for a number of four indicators relating to the "amount of an individual nutrient that people need for good health depending on their age and gender". ${ }^{42}$ In terms of recommended intake, these include a Population Reference Intake value (PRI), which is the level of (nutrient) intake that is adequate for all people in a population group. The intake data is usually based on dietary surveys in several EU countries using food consumption data from the EFSA food consumption database and composition data from the EFSA nutrient composition database.

37 EFSA, Tolerable Upper Intake Levels For Vitamins And Minerals, (February 2006) available at <https://www.efsa.europa.eu/sites/default/files/efsa_rep/blobserver_assets/ndatolerableuil.pdf.>

38 EFSA, Overview on Tolerable Upper Intake Levels as derived by the Scientific Committee on Food (SCF) and the EFSA Panel on Dietetic Products, Nutrition and Allergies (NDA), supra note 37.

39 European Commission Health and Consumer Protection Directorate-General, Orientation Paper on setting maximum and minimum amounts for vitamins and minerals in foodstuffs, supra note 16 , at p. 8.

40 Council Directive 90/496/EEC of 24 September 1990 on nutrition labelling for foodstuffs, OJ 1990 L 276/40.

41 Commission Regulation (EC) No 1169/2011 on the provision of food information to consumers, OJ 2011 L 304/18.

42 EFSA, Overview on Dietary Reference Values for the EU population as derived by the EFSA Panel on Dietetic Products, Nutrition and Allergies (NDA), 4 EFSA Journal (September 2017), at p. 1.

43 See Explanatory Memorandum of the Warenwetbes/uit Toevoeging micro-voedingsstoffen aan levensmiddelen [Commodities Act Decree on the addition of micronutrients to food] 'Warenwetbesluit Toevoeging micro-voedingsstoffen aan levensmiddelen' of May 1996, Statute Book, (hereinafter 'Staatscourant') 1996 , at p. 311.
Table 1 shows the EU standards for harmful amounts and the normative amounts as to how much intake is recommended. It shows the changed EFSA ULs from 2006 to 2018, next to that it also shows the RI values that are used in Regulation (EC) No 1169/2011 on food information to consumers and the PRI values that EFSA recommended in 2017.

As can be seen in Table 1, most of the selected values remained identical, and only the UL of vitamin D changed from 50 to $100 \mu \mathrm{g} /$ day. Regarding the recommended intake, apart for vitamin $\mathrm{A}$, the values were all revised upwards. The PRI values for zinc in 2017 depend on a level of phytate intake, which makes it difficult to compare with the RI from 2011. These values demonstrate the complexities of nutrition and the interaction of processing and nutritional habits with the bioavailability of nutrients.

The SCF had been requested by the European Commission to provide an update for the previous European advice from 1993. Although EFSA provided an updated advice on reference intakes in 2017, so far this did not lead to a change of reference intakes in Regulation (EC) No 1169/2011 on food information to consumers and therefore these RI values remain binding.

On the one hand, we note that since the last attempt of agreeing on maximum levels, new data have been established at EU level. On the other hand, data remains a challenge, as recognized in the Court of Justice case law and - as we show below - the divergent national systems and their methodologies in using available data.

\section{The Netherlands}

Especially the Dutch legal system has been scrutinized by the Court a number of times. In the 1960's in the Netherlands, the limit of the harmful effect of many micronutrients was unknown and insufficient scientific data was available. ${ }^{43}$ In light of the potential harmfulness of these substances and the positive health image, an excessive intake was feared. Consequently, a prohibition on the addition of micronutrients to food was introduced in the Netherlands. In 1996, changes in food supplies, regulations in other countries regarding the addition of micronutrients to food and new scientific insights led to a review of the existing prohibitions in the Netherlands. At that time, the Dutch Nutrition Board 'Gezondheidsraad' 
concluded that under certain circumstances micronutrients were now allowed to be added to foods. For the micronutrients vitamin A (in the form of retinoid), vitamin $D$, folic acid, selenium, copper and zinc this meant that they were only allowed to be added to a restored food or beverage or a substitute product. This led to the introduction of the Dutch 'Warenwetbesluit toevoeging micro-voedingsstoffen aan levensmiddelen'.

\section{Dutch Legal Framework}

In 1996 the Dutch 'Warenwetbesluit toevoeging micro-voedingsstoffen aan levensmiddelen' was introduced. The decree institutes a negative and a positive list. $^{44}$

Art. 5 of this legislation prohibited food fortification with vitamin A (in the form of retinoid), vitamin D, folic acid, selenium, copper and zinc. Food fortification with these vitamins and minerals was not allowed because of the small range between the RDA (the level that is considered sufficient for almost all people in the relevant population) and the UL (the maximum level of total chronic intake of a nutrient from all sources judged to unlikely pose a risk of adverse health effects in humans). Because of this small range, fortification was not safe since it could lead to unacceptable high intakes. ${ }^{45}$ Therefore, exemption for the addition of these micronutrients to food was only granted if, based on the results of the most recent international scientific research, there was no harm to public health. ${ }^{46}$

In 2004, a judgment by the CJEU found that the prohibition of food fortification in the Netherlands contradicted the free movement of goods. ${ }^{47}$ This decision meant that market introduction of a fortified food could only be prohibited if it could be proven that the degree of fortification could harm public health.

Thus, after the judgment of the Court of Justice in 2004, food producers could submit a request to the Minister of Health, Welfare and Sports for an exemption, and submissions were individually evaluated to see if it would lead to an exemption of the prohibition of food fortification. However, this turned out to be an unrealistic approach. Therefore, an investigation was proposed in which it would be determined whether a general exemption could be granted for food fortification with a certain maximum safe amount per micronutrient. There were some existing models at the time that could calculate a maximum food fortification level. ${ }^{48}$ Based on the model by Flynn et al. ${ }^{49}$ a new model was developed that was adapted to the Dutch practical situation of 2006 to derive safe levels of food fortification with micronutrients.

Since 2007, food fortification with folic acid and vitamin D has been allowed in the Netherlands within certain limits. The 'Warenwetbesluit vrijstelling toevoeging foliumzuur en vitamine $D$ aan levensmiddelen' [Commodities Act Decree exemption from adding folic acid and vitamin D to food] introduced an exemption for folic acid and vitamin $\mathrm{D}$ to be added to food in a certain amount. ${ }^{50}$ The rest of Art. 5 from the Commodities Act Decree on the addition of micronutrients to food is still applicable in the Netherlands.

Therefore, vitamin A (in the form of retinoid), selenium, copper and zinc may still only be added to a reconstituted foodstuff or a substitution product, according to Art. 5 of the Dutch 'Warenwetbesluit toevoeging micro-voedingsstoffen aan levensmiddelen'. Until now (2020), vitamin A (in the form of retinoid), selenium, copper and zinc remain on the 'negative list' and are only allowed to be added to a restored or substitute product. As a general rule, food fortification in the strict sense, i.e. pure additions of these vitamins and minerals, is not allowed. However, the Netherlands handles an authorisation system for exemptions from this general rule.

Article 16 of the Dutch Consumer Products Safety Act ('Warenwet') provides for general and individual exemptions. On this basis, the Minister can authorise the marketing of foodstuffs that do not comply with

44 Kugel, P. J. "Admissibility of Fortified Foods and Drinks in the Netherlands." European Food and Feed Law Review 1(2) (2006), pp. 93 et seq.

45 Kloosterman, J., Fransen, H. P., De Stoppelaar, J., Verhagen, H., \& Rompelberg, C., "Safe addition of vitamins and minerals to foods: Setting maximum levels for fortification in the Netherlands", 46(4) European Journal of Nutrition (2007), pp. 220 et sqq.

46 Volksgezondheid, Toevoeging microvoedingsstoffen aan levensmiddelen, 48 (2005) 8-9.

47 Commission v Netherlands, supra note 21.

48 Rasmussen, S. E., Andersen, N. L., Dragsted, L. O., \& Larsen, J. C., "A safe strategy for addition of vitamins and minerals to foods", 45(3) European Journal of Nutrition (2006), pp. 123 et sqq.

49 Flynn, A., et al., "Vitamins and minerals: a model for safe addition to foods", 42(2) European Journal of Nutrition (2003), pp.118 et $s q q$.

50 'Warenwetbesluit vrijstelling toevoeging foliumzuur en vitamine D aan levensmiddelen' of January 2007, Staatscourant, at p.11. 
the prohibitions on food fortifications in the Decree. The conditions for the individual exemptions were specified in a communication in $2005 .{ }^{51}$ The applicant must provide the information about the composition of the food product; its target group; quantitative consumption data; and whether the product will serve as a substitute for another product. In order to conduct this case-by-case risk assessment, results of the most recent international scientific research should be taken into account. In particular the following data will be taken into account: what the average current intake of the concerned substance is from both natural and man-made sources; what the increase will be after market introduction of the product, based on sales expectations; and to what extent the product substitutes a different product with the fortifying nutrients. ${ }^{52}$ The acceptable upper limit of intake (UL) is the level of intake above which there is a chance that undesired effects occur. The Netherlands sets the acceptable upper limit based on the most recent opinions of the Health Council, the Scientific Committee for food or EFSA.

The Dutch fines for violating these provisions have been revised recently. Companies with less than 50 employees can be fined $€_{525}$, while those with more than 50 employees $€ 1.050$. For companies with a turnover of at least $€ 10$ million, the turnover-based fine can be used, which can amount to up to a maximum of $€ 870.000 .^{53}$

51 Publication concerning the addition of micronutrients to foodstuffs ('Bekendmaking toevoeging microvodeingsstoffen aan levensmiddelen'), Staatscourant 9 March 2005, 48, at p. 19.

52 Ibid.

53 See Warenwetbesluit bestuurlijke boeten.

54 When consulting all official announcements, refining for "Toevoeging micro-voedingsstoffen" (addition micro nutrients) on https://zoek.officielebekendmakingen.nl/uitgebreidzoeken. The search results in 3 Besluiten van algemene strekking Nimm2 and folic acid (2010), Katjes and zinc (2019), Arla Shake/pudding and zinc (2020); and 10 Ontheffingen, Marmite and folic acid (2011); energy drink and folic acid (2007); dietmargarine and folic acid (2006, 2006); Nimm2 and folic acid (2005), DIXI and folic acid (2005); breakfast cookies (2005); milk and juice with Vitamin D (2005); breakfast cereals with Vitamin D $(2005,2005)$.

55 Besluit van de Minister voor Medische Zorg van 7 januari 2020, kenmerk 1632453-195489-VGP, houdende ontheffing aan Arla Foods B.V. te Nijkerk van artikel 5 van het Warenwetbesluit Toevoeging micro-voedingsstoffen aan levensmiddelen, available at https://zoek.officielebekendmakingen.nl/stcrt-2020-2337.html.

56 Flynn, "Vitamins and minerals: a model for safe addition to foods" supra note 54

57 Ibid.

58 'Warenwetbesluit vrijstelling toevoeging foliumzuur en vitamine D aan levensmiddelen' of January 2007, Staatscourant, 2007, at p. 11
Between 2005 and now, 13 authorisations were granted. ${ }^{54}$ To take an example, a recent authorisation for shake/pudding and zinc ${ }^{55}$ limited the amount of zinc to $1,2 \mathrm{mg}$ zinc per $100 \mathrm{ml}$ for the shake and 0,75 $\mathrm{mg}$ zinc per $100 \mathrm{~g}$ pudding. The authorisation further stipulates that specific mandatory indications must be labelled: that the product is 'only for adults', the amount of shakes/puddings per day and that this advice should not be exceeded and also that these shakes/puddings should not be consumed in combination with food supplements with zinc.

\section{Dutch Scientific Basis}

In 1996, changes in food supplies, regulations in other countries regarding the addition of micronutrients to food and new scientific insights led to a review of the existing prohibition of food fortification in the Netherlands. Because of the small range between the tolerable upper intake levels (ULs) and the Recommended Daily Averages (RDA's) (see Figure 1) and the lack of proof of a nutritional need, food fortification with vitamin A (in the form of retinoid), vitamin D, folic acid, selenium, copper and zinc remained prohibited in the Netherlands.

The addition of these six micronutrients was only allowed in the case of a substitution product or a reconstituted foodstuff. Hence, other food fortification with vitamin $\mathrm{A}$ (in the form of retinoid), vitamin D, folic acid, selenium, copper and zinc is not allowed.

Due to the 2004 CJEU judgment, a new model to derive safe level of food fortification with micronutrients was developed, based on the model by Flynn et al., ${ }^{56}$ which was adapted to the Dutch practical situation in 2006.

The model by Flynn et al. ${ }^{57}$ was used because it sets the food fortification level per $100 \mathrm{kcal}$. The assumption underlying this model is that, on average, an individual never consumes more than $3600 \mathrm{kcal}$ (i.e. an indication of energy intake of high consumers - this exceed the energy intake of $95 \%$ of consumers, derived from large scale surveys of food consumption in European countries). Since an individual on average will not consume more than $3600 \mathrm{kcal}$, there will not be a risk that an individual will consume too much of a certain micronutrient. In 2007, the Dutch policy 'Warenwet vrijstelling toevoeging foliumzuur en vitamine D aan levensmiddelen ${ }^{58}$ allowed food 
fortification with folic acid with $100 \mu \mathrm{g} / 100 \mathrm{kcal}$ and vitamin D with $4,5 \mu \mathrm{g} / 100 \mathrm{kcal}$.

According to the explanatory memorandum of 'Warenwet vrijstelling toevoeging foliumzuur en vitamine D aan levensmiddelen ${ }^{59}$, when assessing whether or not a request for exemption could be granted and how much folic acid and / or vitamin D could be added, the so-called approach per product category was used. This approach led to the theoretical conclusion that there would be no room for further addition of vitamin D and folic acid to food (the so-called free space would have already been filled), while that was not very realistic in practice. This has led to this exemption regulation. ${ }^{60}$

In 2017, new RDA's and UL's were developed by EFSA (see Table 1), however these new values have not led to changes in the Dutch food fortification legislation. The main reason not to allow food fortification as stated before, according to the Ministry of VWS, is the small range between the RDA and the UL. A safe level of intake would then not be much higher than the RDA and therefore food fortification is not allowed ${ }^{61}$ This is still the main argument for not allowing fortification with vitamin A (in the form of retinoid), selenium, copper and zinc. Table 2 presents the differences between the RDA's and UL's in 1996 and 2018 for vitamin A (in the form of retinoid), vitamin $D$, folic acid, selenium, copper and zinc. The overview shows whether there have been changes in the RDA's and ULs over time and whether it could explain why fortification with these vitamins and minerals is still not allowed. Since the RDA was unknown in 1996, the Adequate Intake (AI) values were used. If the average requirement is unknown, the RDA cannot be determined. In that case, based on the available research, it is estimated what the lowest amount that seems to be sufficient for almost all people in that group is; this is the so-called AI. ${ }^{62}$

As can be seen in Table 2, only the AI/RDA and UL for vitamin D have changed substantially. For folic acid, there was no UL in 1996 and was set at 1000 $\mu \mathrm{g} /$ day in 2018 . Focussing on the range between the UL and the RDA, it can be seen that for most micronutrients presented in table 1 , the RDA and UL changed over the years. For zinc however, the range between the RDA and UL remained the same.

The Dutch RDA's of 2018 are based on an evaluation by the Ministry of VWS of the RDA's provided by EFSA. Only the RDA for selenium provided by EFSA is adopted. According to the Ministry of VWS the RDA's for vitamin A, vitamin D, folic acid, copper and zinc provided by EFSA could not be properly judged because of a lack of research. ${ }^{63}$

Regarding the UL's, these values presented in table 1 are the same for all European countries. It is the maximum level of total chronic intake of a nutrient from all sources judged to unlikely pose a risk of adverse health effects in humans. Every European country takes over the UL value determined by EFSA, since they do not depend on average intakes of a country for example, as with the RDA's.

\section{Belgium}

In contrast to the Netherlands, Belgium allows food fortification with vitamin A (in the form of retinoid), selenium, copper and zinc. This chapter presents the background of the food fortification legislations in Belgium and presents the Belgian RDA and the RI/PRI according to EFSA.

\section{Belgian Legal Framework}

In 1992 the Belgian legislation on the addition of micronutrients to food came into force. ${ }^{64}$ As stated in this legislation there was an urgent necessity at that time to implement a legislation that concerned the placing on the market of nutrients and foods to which nutrients were added. There are certain requirements that fortified foods must meet. ${ }^{65}$

Apart from the notification file, the intake of either the daily portion of the food recommended on the label or an amount of the food equal to its average daily consumption as determined in Appendix 2 may not result in the total amount of the nutrients included on the label: (a) less than $15 \%$ of the recom-

59 Ibid.

60 lbid.

61 Volksgezondheid, Toevoeging microvoedingsstoffen aan levensmiddelen, supra note 51 .

62 Gezondheidsraad, Voedingsnormen voor vitamines en mineralen voor volwassenen, supra note 36 .

63 Voedingsraad, N. (1989). Nederlandse voedingsnormen 1989. Den Haag: voorlichtingsbureau voor de voeding.

64 Koninklijk Besluit van 3 Maart 1992 betreffende het in de handel brengen van nutriënten en van voedingsmiddelen waaraan nutriënten werden toegevoegd (B.S. 15.IV.1992), 1992.

65 Ibid, Article 3. 
mended daily allowance for those nutrients in Annex 1; (b) is higher than: (ba) $150 \%$ of the recommended daily allowance for nutrients marked with an asterisk*; (bb) $300 \%$ of the recommended daily allowance for vitamins B, C, E, H and K in Annex 1; (bc) $200 \%$ of the recommended daily allowance for nutrients other than those referred to in ba) and bb). ${ }^{66}$ Hence, this article provides the minimum and maximum levels for fortification with different types of nutrients.

Before a fortified food can be placed on the market, a notification file shall be submitted to the authority. A notification file should contain among others: the nature of the product, the complete ingredient list with the added micronutrients, a nutritional analysis, data about the presence and non-toxicity of the active substances, the artwork of the product and the necessary information enabling the nutritional value to be assessed. ${ }^{67}$ In the processing of this notification file, verifications are performed on the draft label and the declared composition of the product.

\section{Belgian Scientific Basis}

Vitamin A (in the form of retinoid), vitamin D, selenium, copper and zinc belong to the categories marked with an asterisk, thus the maximum amount that can be added must not be higher than $150 \%$ of the stated Belgian RDA for these vitamins and minerals. For folic acid, this is $200 \%$ (see table 3 ).

Taking the example of milk as an example. According to appendix 2, the average daily consumption of milk is $200 \mathrm{~g}$. This means that $200 \mathrm{~g}$ of milk has a maximum fortification amount of $1200 \mu \mathrm{g}$ for vitamin A (see table 3).

In September 2017, Belgium changed their regulation on the addition of micronutrients to food. An important reason to change this regulation was an extensive update of the nutritional recommendations for the Belgian Population of the Superior

66 Ibid, Article 3.

67 Ibid, Article 4

68 Koninklijk besluit tot wijziging van het koninklijk besluit van 3 Maart 1992 betreffende het in de handel brengen van nutriënten en van voedingsmiddelen waaraan nutriënten werden toegevoegd, (19 September 2017), as stated in the Belgian Official Gazette of 31 October 2017, available at http://www.ejustice.just.fgov.be/eli/besluit/2017/09/19/2017013412/staatsblad einde.

69 HGR, Gezondheidsraad Voedingsaanbevelingen voor België, 2016 September 2016, Nr. 9285.
Health Council of Belgium. ${ }^{68}$ The Superior Health Council of Belgium based these Belgian RDA's on the recommendations of EFSA and expert committees from other countries. ${ }^{69}$ This led to specific Belgian RDA's for vitamin A (in the form of retinoid), vitamin D, folic acid, selenium, copper and zinc, as can be seen in table 3. Among other things based on these new Belgian RDA's, new maximum amounts for food fortification were calculated, which are stated in the appendix of the new regulation and are also mentioned in table 3 .

Comparing the values in table 3 , it can be seen that the Belgian RDA of vitamin D, folic acid and copper increased, which also led to an increase of the maximum food fortification amounts of these micronutrients. However, the RDA of zinc and vitamin A (in the form of retinoid) decreased and the maximum food fortification amount remained the same. For selenium, the Belgian RDA and food fortification amount remained the same.

Hence, food fortification with vitamin A (in the form of retinoid), vitamin $D$, selenium, folic acid, copper and zinc has been allowed in Belgium since 1992. In 2017, Belgium changed the RDA's of these micronutrients (as can be seen in table 1 and 2) and as a result, the maximum food fortification amounts changed as well.

\section{Interaction Between Different Scientific Evidences for Food Fortification}

Since the Netherlands and Belgium have different food fortification legislation, the next chapter discusses differences that could explain these different legislations. Firstly, it compares the Dutch RDA, Belgian RDA and European PRI/RI with the UL. Thereafter, it compares the observed average intakes of vitamin A (in the form of retinol), vitamin D, folic acid, selenium, copper and zinc in the Netherlands, Belgium and the EU.

\section{Comparison of the Recommended Amounts: Dutch and Belgian RDA's and European RI/PRI}

According to the Dutch ministry of VWS, the main reason why food fortification with certain micronu- 
trients is not allowed, is because the range between the RDA and the UL is too small. This means that if the recommended and the safe levels are very close to one another, food fortification is regulated more stringently. Table 4 compares the range between the RDA and the UL in the Netherlands, Belgium and the EU.

Comparing the EU RI and PRI, over time, all of the values were adjusted. Apart from Selenium, there remains some variation between these recommended amounts at EU level and the nationally established recommendations. Comparing the ranges between the different RDA's/RI/PRI and the UL, they do not seem to differ a lot. Therefore, it seems that the argument that the range between the RDA and the UL is too small, does not count for Belgium or the EU.

Based on recommendations by EFSA and expert committees from other countries, Belgium changed their RDA's in $2016 .^{70}$ This explains why the BE RDA's and EU RI (which was developed in 2011) are fairly close together. According to the literature, the development of NL RDA and the BE RDA came about differently. In the Netherlands, a report by the Ministry of VWS discussed the applicability of the PRI's set by EFSA for the Dutch population. This led to different RDA's than the PRI's that EFSA provided for the vitamins $A$ and $D$, folic acid, copper and zinc (as can be seen in table 4). For vitamin A (in the form of retinoid), the reason for the Netherlands to develop a different RDA was the specific context of the Netherlands. Vitamin D, folic acid, copper and zinc were not copied from EFSA because the Ministry of VWS did not agree with the substantiation of these RDA's. ${ }^{71}$ For zinc, according to the Ministry of the VWS, the PRI was insufficiently substantiated due to the fact that research is hardly or not available.

Thus, a main difference between the Netherlands and Belgium is the fact that the Netherlands discusses the applicability of the RI's/PRI's provided by EFSA whereas Belgium based their RDA's on the recommendations by EFSA and did not re-evaluate the substantiation of the RDA's provided by EFSA. ${ }^{72}$

\section{Differences in the Average Intakes Between the Netherlands, Belgium and the EU}

Next to the different RDA's between the Netherlands and Belgium, the main difference for food fortifica- tion levels between the two countries could possibly be explained by a significant variation in the average intakes per day of micronutrients in Belgium, the Netherlands and the EU. Table 5 provides the different average intakes of vitamin A (in the form of retinol), vitamin $\mathrm{D}$, folic acid, selenium, copper and zinc in the Netherlands, Belgium and the EU.

As presented in table 5, Rijksinstituut voor Volksgezondhheid en Milieu (RIVM) (the national institute for public health and environment) of the Netherlands provides specific average intakes of vitamins and minerals for the Dutch population, measured between 2012 and 2016. Based on different scientific sources, we collected average intakes of vitamin A (in the form of retinol), vitamin D and selenium for the Belgium population. ${ }^{73}$ There was no data available on average intakes for the Belgian population for copper and zinc. For the European average intakes, EFSA takes data from dietary sources from different countries within the EU. Based on that data they provide an average dietary intake range, as can be seen in table 5 . Comparing the values that could be found for the Netherlands, Belgium and the $\mathrm{EU}$, they do not seem to substantially differ.

Based on this data, the difference in average intakes does not seem to be a reason for Belgium and the Netherlands to have such different fortification amounts.

\section{Discussion}

Since the EU has not established maximum limits in legislation, Member States remain free to regulate the issue, in particular through authorisation schemes. These schemes have to comply with Arti-

70 HGR, Gezondheidsraad Voedingsaanbevelingen voor België, 2016 September 2016, Nr. 9285.

71 Gezondheidsraad, Voedingsnormen voor vitamines en mineralen voor volwassenen, supra note 36.

72 HGR, Gezondheidsraad Voedingsaanbevelingen voor België, 2016 September 2016, Nr. 9285.

73 Therefore, comparing the average intakes of folic acid, copper and zinc within the Netherlands, Belgium and EU is not possible. Only for vitamin A (in the form of retinol), vitamin D, and selenium specific average intakes for Belgium could be found. For folic acid it is unknown, because the data presented in nationally representative surveys lack comparability for various reasons. Bouckaert, K. P. et al., "Critical evaluation of folate data in European and international databases: recommendations for standardization in international nutritional studies", 55(1) Molecular Nutrition \& Food Research (2011), pp. 166 et sqq. 
cle 34 and 36 TFEU, as well as the risk assessment criteria in the Directive. The CJEU has been confronted with a number of cases questioning the legality of specific authorisation schemes in Member States. The Court was eager to underline that Member States enjoy a large margin of discretion with respect to the justification of authorisation schemes under public health, especially when there is scientific uncertainty about the potential harms of adding vitamins, minerals, and other substances. The Court does, however, set up relatively strict requirements on the design of national authorisation schemes - these mostly relate to the fact that national measures cannot issue 'blanket bans' on fortification, but must specifically address the nutrients and respective risks on a case by case basis. The Court also institutes important procedural safeguards, such as accessibility and reasonableness of time.

The initial ambitions of the Regulation, namely the harmonisation of the fortified food market, has been not been achieved. The reasons speaking in favour of harmonisation nowadays appear as pertinent as during the time of introduction of the Regulation. The low number of 13 individual authorisations in 15 years in the Dutch context indicate that the authorisation system does not ensure permeability of the Dutch market for fortified products. Anecdotal evidence confirms that traders find the authorisation system onerous, to say the least, and that non-authorised products circulate on the national markets frequently.

The reason why the European Commission did not proceed with setting the maximum amounts relate to the lack of scientific data about the inherent risks of different micronutrients. In setting maximum limits, the upper safe levels, the intake from other dietary sources and reference (recommended) intakes should be taken into account. At EU level, EFSA has established upper safe levels (ULs), as well as recommended intakes (RI and PRI). In the respective scientific opinions on nutritional values, EFSA also established average intake ranges. In terms of availability of necessary data at EU level, significant progress has been made since the last round of consultation by the EC with the Member States. Prima facie, there appears to be more data available that could serve as a basis for setting the maximum levels at EU level for many if not all vitamins and minerals. At the very least, the European Commission should restart the drawing up of a list of maximum addition, as at least for some vitamins, minerals and other substances it is likely that scientific consensus can be established on a case by case basis.

Looking at the national authorisation schemes, the case studies showed that, despite relatively similar contexts, national legal systems differ. For instance, in the Netherlands it is not allowed to fortify foods with vitamin A (in the form of retinoid), selenium, copper and zinc apart from a substitution product or a reconstituted foodstuff, unless an exemption is issued. By contrast, in Belgium food fortification with these minerals is allowed within certain limits.

The study of the Dutch and the Belgian legal system demonstrated two vital differences in their authorisation systems at national level: whether EU or national nutritional values are used and methodologies used to establish maximum levels.

Regarding the nutritional values, the Dutch case demonstrated that countries may find it necessary to modify 'EU' nutritional values for application at national level. This stems from the fact that the dietary profiles can vary at national level, thus resulting in diverse national needs. Subsidiarity in such a case would call for regulation at the lowest possible level. Only a rather large discrepancy in average intakes would support the idea that maximum fortification levels should be set at national level. If they are more or less the same, then the EU level would make more sense. In line with this, it is important to note that the idea of 'national diets' is becoming an increasingly unempirical one. Dietary patterns have been dramatically de-nationalised with the globalisation of food products and the overwhelming acceptance of 'foreign' cuisine. Dietary patterns are also regionally determined (for instance, through the availability of fish) and represent more and more individual and transnational choices (vegetarian; diets that are low in sugars, fats or carbohydrates). In this light, it is questionable in how far specific national nutrition values are valid for setting maximum levels. Establishing maximum levels that are consistent across EU diets then could actually make food safer rather than less safe.

Regarding the methodologies deployed, we equally observed significant divergence in the underlying models: the Netherlands work with an approach based on the overall caloric intake of citizen, while Belgium works with the expected consumption of specific foodstuffs. The Belgian approach requires to make an estimate of individual food consumption. 
The Dutch approach is more easily administered in that the reference value is the total caloric consumption and therefore does not require specific consumption data. If regulation is done at EU level, in terms of methodology, it will be crucial to answer the question of how to methodologically tackle how diverse dietary sources contribute to the overall intake.

EU internal market regulation has long favoured information requirements over market bans. One should therefore consider in how far food fortification information could replace or meaningfully supplement market restrictions. On a case by case basis, it could be evaluated whether labelling constitutes a proportional measure that adequately addresses inherent risks. A possibility would be to mention the UL and RDA on the label and make the consumer responsible for the intake amount. The information provided should also inform consumers about the potential harms, as well as information about specific alternative relevant dietary sources of a given nutrient. Consumers have the best insight into their in- dividual consumption habits. Information requirements instead of market bans seems to be particularly warranted in light of the fact that the harms of excess consumption materialise only in the long term, and not upon a one-time overconsumption. Risks may be higher for specific groups (for instance Vitamin A for pregnant women), and in such cases targeted information may be more proportional to blanket prohibitions.

In light of the strong trend in the direction of functional foods, the EU legislator should resume the stalled legislative efforts to tackle the question of food fortification. While without a doubt a complex nutritional challenge, we have found no arguments to support that it would be better tackled at national level.

In anticipation of the strengthening of the foodhealth nexus, a well-functioning food fortification market ordering that allows for safe innovation and free marketing will strengthen the position of EU market players and safely improve nutritional possibilities for EU citizen. 


\section{Appendix}

Table 1: The UL (in 2006 and in 2018) set by EFSA and the RI in 2011 and the PRI in 2017 (for vitamin A, D, folic acid, selenium, copper and zinc.

\begin{tabular}{|c|c|c|c|c|}
\hline & \multicolumn{2}{|l|}{ Maximum daily amounts } & \multicolumn{2}{|c|}{ Recommended intakes } \\
\hline & \multicolumn{2}{|l|}{ Harmful amounts } & \multicolumn{2}{|l|}{ Normative amounts } \\
\hline & $\frac{\text { UL 2006 }{ }^{\mathrm{a}}(\text { EFSA Opin- }}{\underline{\text { ion })}}$ & $\frac{\mathrm{UL} 2018^{\mathrm{b}}(\mathrm{EFSA}}{\underline{\text { Opinion) }}}$ & $\frac{\text { RI } 2011^{c}(\text { Used in }}{\underline{\text { FICR })}}$ & $\underline{\text { PRI } 2017^{\mathrm{d}} \text { (EFSA Opinion) }}$ \\
\hline $\begin{array}{l}\text { Vitamin A } \\
\text { ( } \mu \mathrm{g} R \mathrm{R} / \text { day) }\end{array}$ & 3000 & 3000 & 800 & $7500650 \%$ \\
\hline Vitamin D ( $\mu \mathrm{g} /$ day) & 50 & 100 & 5 & 15 \\
\hline Folic Acid ( $\mu \mathrm{g} /$ day) & 1000 & 1000 & 200 & 330 \\
\hline Selenium ( $\mu \mathrm{g} /$ day) & 300 & 300 & 55 & 70 \\
\hline Copper (mg/day) & 5 & 5 & 1 & $1,60^{*} 1,3$ 우 \\
\hline Zinc (mg/day) & 25 & 25 & 10 & $9,4-16,3 o^{\star} * 7,5-12,7 q *$ \\
\hline
\end{tabular}

a EFSA, Tolerable Upper Intake Levels For Vitamins And Minerals, supra note 38.

b EFSA, Overview on Tolerable Upper Intake Levels as derived by the Scientific Committee on Food (SCF) and the EFSA Panel on Dietetic Products, Nutrition and Allergies (NDA), supra note 42.

C Commission Regulation (EC) No 1169/2011, supra note $X$

d EFSA, Overview on Dietary Reference Values for the EU population as derived by the EFSA Panel on Dietetic Products, Nutrition and Allergies (NDA), supra note 43.

* Depending on the level of phytate intake per day (300-1200 mg/day). 
Table 2: ULs and AI/RDA's in the Netherlands for adults in 1996 and 2018

\begin{tabular}{|c|c|c|c|c|c|c|}
\hline & \multicolumn{2}{|c|}{ Maximum daily amounts } & \multicolumn{3}{|c|}{ Recommended intakes } & Fortification amounts \\
\hline & \multicolumn{2}{|c|}{ Harmful amounts } & \multicolumn{3}{|c|}{ Normative amounts } & Legal amounts \\
\hline & $\underline{\mathrm{UL}}_{1996^{\mathrm{a}}}$ & $\underline{\mathrm{UL}} 2017^{\mathrm{b}}$ & 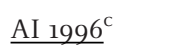 & ${\underline{\mathrm{RDA}} 2018^{\mathrm{d}}}$ & Fortification amounts 2007 & \\
\hline $\begin{array}{l}\text { Vitamin A } \\
\text { ( } \mu \text { g RE/day) }\end{array}$ & $\begin{array}{l}200 \mathrm{RE} / \mathrm{kg} \\
\text { body weight }\end{array}$ & 3000 & $10000^{\pi} 800 q$ & $8000^{\pi} 680$ q & $\begin{array}{l}\text { Not allowed, unless autho- } \\
\text { rised. }\end{array}$ & \\
\hline $\begin{array}{l}\text { Vitamin D } \\
(\mu g / \text { day })\end{array}$ & 25 & 100 & $0-2,5$ ôt & 10 & $4,5 \mu \mathrm{g} / 100 \mathrm{kcal}$ & \\
\hline $\begin{array}{l}\text { Folic Acid } \\
(\mu \mathrm{g} / \text { day })\end{array}$ & - & 1000 & $200-300 \delta^{\lambda} q$ & 300 & $100 \mu \mathrm{g} / 100 \mathrm{kcal}$ & \\
\hline $\begin{array}{l}\text { Selenium } \\
(\mu \mathrm{g} / \mathrm{day})\end{array}$ & 200 & 300 & $50-150$ ơ? & 70 & $\begin{array}{l}\text { Not allowed, unless autho- } \\
\text { rised. }\end{array}$ & \\
\hline $\begin{array}{l}\text { Copper } \\
(\mathrm{mg} / \text { day })\end{array}$ & $\begin{array}{l}\text { O, } 5 \mathrm{mg} / \mathrm{kg} \\
\text { food }\end{array}$ & 5 & $1,5-3,5 \delta^{7} q$ & 0,9 & $\begin{array}{l}\text { Not allowed, unless autho- } \\
\text { rised. }\end{array}$ & \\
\hline $\begin{array}{l}\text { Zinc } \\
\text { (mg/day) }\end{array}$ & 25 & 25 & $\begin{array}{l}7-100^{\top} 6-9 \\
q\end{array}$ & $90^{\pi} 79$ & $\begin{array}{l}\text { Not allowed, unless autho- } \\
\text { rised. }\end{array}$ & \\
\hline
\end{tabular}

a Voedingsraad, N. (1989). Nederlandse voedingsnormen 1989. Den Haag: voorlichtingsbureau voor de voeding.

b EFSA, Overview on Tolerable Upper Intake Levels as derived by the Scientific Committee on Food (SCF) and the EFSA Panel on Dietetic Products, Nutrition and Allergies (NDA), supra note 37.

c Voedingsraad, N. (1989). Nederlandse voedingsnormen 1989. Den Haag: voorlichtingsbureau voor de voeding.

d Gezondheidsraad, Voedingsnormen voor vitamines en mineralen voor volwassenen, supra note 36. 
Table 3: RDA's and maximum food fortification amounts per average daily use of a food product for vitamin A (in the form of retinoid), vitamin D, folic acid, selenium, copper and zinc in Belgium in 1992 and 2017

\begin{tabular}{|c|c|c|c|c|c|c|}
\hline & \multicolumn{2}{|c|}{ Maximum daily amounts } & \multicolumn{2}{|c|}{ Recommended intakes } & \multicolumn{2}{|c|}{ Fortification amounts } \\
\hline & \multicolumn{2}{|c|}{ Harmful amounts } & \multicolumn{2}{|c|}{ Normative amounts } & \multicolumn{2}{|l|}{ Legal amounts } \\
\hline & $\underline{\mathrm{UL}}_{1996^{\mathrm{a}}}$ & ${\underline{\mathrm{UL}} 2017^{b}}^{\mathrm{b}}$ & $\underline{\text { RDA } 1992}$ & $\underline{\text { RDA } 2017}$ & 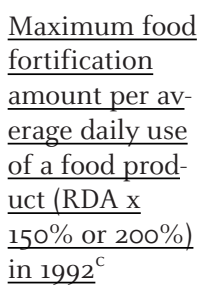 & $\begin{array}{l}\frac{\text { Maximum food }}{\text { fortification }} \\
\frac{\text { amount per av- }}{\text { erage daily use }} \\
\frac{\text { of a food prod- }}{\text { uct (RDA x }} \\
\frac{150 \% \text { or } 200 \%)}{\text { in } 2017^{\mathrm{d}}}\end{array}$ \\
\hline $\begin{array}{l}\text { Vitamin A ( } \mu \mathrm{g} \\
\mathrm{RE} / \text { day) }\end{array}$ & $\begin{array}{l}200 \mathrm{RE} / \mathrm{kg} \\
\text { body weight }\end{array}$ & 3000 & 800 ( $\mu \mathrm{g} /$ day $)$ & $\begin{array}{l}750(\mu \mathrm{g} / \text { day }) \sigma^{\pi} \\
650(\mu \mathrm{g} / \text { day }) \text { o }\end{array}$ & $1200 \mu \mathrm{g}$ & $1200 \mu \mathrm{g}$ \\
\hline $\begin{array}{l}\text { Vitamin D } \\
\text { ( } \mu \mathrm{g} / \text { day) }\end{array}$ & 25 & 100 & 5 ( $\mu \mathrm{g} /$ day) & 10-15 ( $\mu \mathrm{g} /$ day) & $7,5 \mu \mathrm{g}$ & $75 \mu \mathrm{g}$ \\
\hline $\begin{array}{l}\text { Folic Acid } \\
(\mu \mathrm{g} / \text { day })\end{array}$ & - & 1000 & 200 ( $\mu \mathrm{g} /$ day $)$ & 200-300 ( $\mu \mathrm{g} /$ day) & $400 \mu g$ & $500 \mu \mathrm{g}$ \\
\hline $\begin{array}{l}\text { Selenium } \\
(\mu \mathrm{g} / \text { day })\end{array}$ & 200 & 300 & 70 ( $\mu \mathrm{g} /$ day) & $70(\mu \mathrm{g} / \text { day })^{*}$ & $105 \mu g$ & $105 \mu g$ \\
\hline $\begin{array}{l}\text { Copper } \\
\text { (mg/day) }\end{array}$ & $\begin{array}{l}0,5 \mathrm{mg} / \mathrm{kg} \\
\text { food }\end{array}$ & 5 & 1,1 (mg/day) & $\begin{array}{l}1,7(\mathrm{mg} / \text { day }){ }^{\pi} \\
1,2(\mathrm{mg} / \text { day }) ~\end{array}$ & $1,65 \mathrm{mg}$ & $2 \mathrm{mg}$ \\
\hline Zinc (mg/day) & 25 & 25 & 15 (mg/day) & $\begin{array}{l}11 \text { (mg/day) o } \\
8 \text { (mg/day) } q\end{array}$ & $22,5 \mathrm{mg}$ & $22,5 \mathrm{mg}$ \\
\hline
\end{tabular}

a Voedingsraad, N. (1989). Nederlandse voedingsnormen 1989. Den Haag: voorlichtingsbureau voor de voeding.

b EFSA, Overview on Tolerable Upper Intake Levels as derived by the Scientific Committee on Food (SCF) and the EFSA Panel on Dietetic Products, Nutrition and Allergies (NDA), supra note 37.

c Koninklijk Besluit van 3 Maart 1992 betreffende het in de handel brengen van nutriënten en van voedingsmiddelen waaraan nutriënten werden toegevoegd (B.S. 15.IV.1992), 1992.

d Koninklijk Besluit van 3 Maart 1992 betreffende het in de handel brengen van nutriënten en van voedingsmiddelen waaraan nutriënten werden toegevoegd (B.S. 31.X.2017), 2017.

* For Selenium, this is an Al instead of a RDA, because EFSA has not been able to derive a reliable RDA. See, EFSA NDA Panel, Scientific Opinion on Dietary Reference Values for Selenium, (2014) EFSA Journal, 12 (10:3846), 67. 
Table 4: RDA's for the Netherlands and Belgium and the PRI and UL set by EFSA

\begin{tabular}{|c|c|c|c|c|c|c|}
\hline & \multicolumn{4}{|c|}{ Adequate intakes } & $\begin{array}{l}\text { Maximum dai- } \\
\text { ly amounts }\end{array}$ & Associated risks \\
\hline & \multicolumn{4}{|c|}{ Normative amounts } & \multicolumn{2}{|c|}{ Harmful amounts } \\
\hline & $\begin{array}{l}\frac{\text { RI } 2011 \text { ac- }}{\text { cording to }} \\
\frac{\text { Regulation }}{\underline{\text { EC }) \text { No }}} \\
\underline{1169 / 2011}\end{array}$ & $\frac{\frac{\text { PRI set by }}{\text { EFSA in }}}{\underline{2017}}$ & $\underline{\underline{\text { RDA NL in }}}$ & $\frac{\text { RDA BE in }}{\underline{2017}}$ & $\frac{\text { UL set by }}{\text { EFSA in } 2017}$ & $\underline{\text { Effects of excessive intake }}$ \\
\hline $\begin{array}{l}\text { Vitamin A ( } \mu \mathrm{g} \\
\text { RE/day) }\end{array}$ & 800 & $\begin{array}{l}7500050 \\
+\end{array}$ & $8000^{\lambda} 680$ ㅇ & $\begin{array}{l}7500650 \\
\text { o }\end{array}$ & 3000 & $\begin{array}{l}\text { Signs and symptoms of acute } \\
\text { and chronic hypervitaminosis. }\end{array}$ \\
\hline $\begin{array}{l}\text { Vitamin D } \\
(\mu g / \text { day })\end{array}$ & 5 & 15 ठే? & 10 ợ & $10-15$ & 100 & 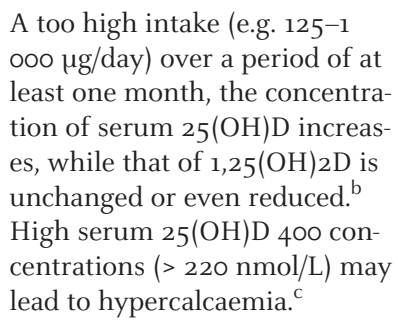 \\
\hline $\begin{array}{l}\text { Folic Acid } \\
(\mu g / \text { day })\end{array}$ & 200 & $330 \delta^{-1}+$ & $3000^{7}+9$ & $\begin{array}{l}200-300 \\
\text { ơo }\end{array}$ & 1000 & $\begin{array}{l}\text { The UL has been set based on } \\
\text { safety concerns for high intake } \\
\text { of the synthetic form of the vit- } \\
\text { amin folate, i.e. folic acid, and } \\
\text { these are related mainly to indi- } \\
\text { viduals with cobalamin defi- } \\
\text { ciency. }\end{array}$ \\
\hline
\end{tabular}

a Biesalski HK,. "Comparative assessment of the toxicology of vitamin A and retinoids in man", 57 Toxicology (1989), pp. 117 et sqq.

b EFSA NDA Panel, Scientific Opinion on the Tolerable Upper Intake Level of Vitamin D, 10(7) EFSA Journal (2012), 2813.

c Vieth R, "Vitamin D supplementation, 25-hydroxyvitamin D concentrations, and safety" 69 American Journal of Clinical Nutrition (1999), pp. 842 et sqq.

d EFSA NDA Panel, Scientific Opinion on Dietary Reference Values for Folate, 22 EFSA Journal (2014). 
Table 4 (Continued): RDA's for the Netherlands and Belgium and the PRI and UL set by EFSA

\begin{tabular}{|c|c|c|c|c|c|c|}
\hline & \multicolumn{4}{|c|}{ Adequate intakes } & Maximum dai- & Associated risks \\
\hline & \multicolumn{4}{|c|}{ Normative amounts } & \multicolumn{2}{|c|}{ Harmful amounts } \\
\hline & $\frac{\frac{\text { RI } 2011 \mathrm{ac}^{-}}{\text {cording to }}}{\frac{\text { Regulation }}{(\mathrm{EC}) \mathrm{No}}} \frac{1169 / 2011}{\underline{1109}}$ & $\frac{\frac{\text { PRI set by }}{\text { EFSA in }}}{\underline{2017}}$ & $\frac{\underline{R D A} N L \text { in }}{\underline{2018}}$ & $\frac{\text { RDA BE in }}{\underline{2017}}$ & $\frac{\text { UL set by }}{\underline{\text { EFSA in } 2017}}$ & Effects of excessive intake \\
\hline $\begin{array}{l}\text { Selenium } \\
\text { ( } \mu \mathrm{g} / \text { day) }\end{array}$ & 55 & $700^{\top} q$ & 70 ơ $^{\top}+$ & $700^{\top} \phi$ & 300 & $\begin{array}{l}\text { Chronic excess of body seleni- } \\
\text { um can give rise to selenosis } \\
\text { occurring in population groups } \\
\text { (e.g. in China) exposed to levels } \\
\text { of dietary selenium above } 1 \text { ooo } \\
\mu \mathrm{g} / \text { day. }\end{array}$ \\
\hline $\begin{array}{l}\text { Copper } \\
\text { (mg/day) }\end{array}$ & 1 & 1,6 ôl1,3우 & $0,90^{\top} q$ & $\begin{array}{l}1,70 \\
1,29\end{array}$ & 5 & $\begin{array}{l}\text { An excess of copper has been } \\
\text { recorded and shown to cause } \\
\text { problems only under certain } \\
\text { specific conditions, notably ge- } \\
\text { netic disorders such as Wilson } \\
\text { disease. }^{f}\end{array}$ \\
\hline Zinc (mg/day) & 10 & $\begin{array}{l}9,4-16,3 \\
0^{*} 7,5^{-} \\
12,7 \%^{*}\end{array}$ & $90^{\pi} 79$ & $\begin{array}{l}110 \\
8 \%\end{array}$ & 25 & $\begin{array}{l}\text { Chronic high zinc intake can } \\
\text { result in severe neurological } \\
\text { diseases attributable to copper } \\
\text { deficiency. }\end{array}$ \\
\hline
\end{tabular}

e Yang G, et al., "Studies of safe maximal daily dietary selenium intake in a seleniferous area in China. I. Selenium intake and tissue selenium levels of the inhabitants", 3(2) Journal of Trace Elements and Electrolytes in Health and Disease (1989), pp. 77 et sqq.

f Tanzi RE, et al., "The Wilson disease gene is a copper transporting ATPase with homology to the Menkes disease gene", 5 Nature Genetics (1993), pp. 344 et sqq.

g Hedera P, et al., "Myelopolyneuropathy and pancytopenia due to copper deficiency and high zinc levels of unknown origin II. The denture cream is a primary source of excessive zinc", 30 Neurotoxicology (2009), pp. 996 et sqq. 
Table 5: Average intakes of the micronutrient's vitamin D, folic acid and zinc in the Netherlands, Belgium and $E U$

\begin{tabular}{|c|c|c|c|}
\hline & $\begin{array}{l}\text { Average intake in the } \\
\text { Netherlands (2012-2016) (in- } \\
\text { cluding food supplements) }\end{array}$ & $\begin{array}{l}\text { Average intake in Belgium } \\
\text { (2014-2017) (including food } \\
\text { supplements) }\end{array}$ & $\begin{array}{l}\text { Average intake in Europe } \\
(2012-2016)\end{array}$ \\
\hline & \multicolumn{3}{|l|}{ Empirical amounts } \\
\hline Vitamin A ( $\mu \mathrm{g}$ RE/day) & 858 & $853-1065^{b}$ & $816-1498^{c}$ \\
\hline Vitamin D ( $\mu g /$ day) & 5 & $6,15-13,15^{d}$ & $3,1-23,5^{\mathrm{e}}$ \\
\hline Folic Acid ( $\mu \mathrm{g} /$ day) & 328 & Unknown $^{f}$ & Unknown ${ }^{\mathrm{g}}$ \\
\hline Selenium ( $\mu \mathrm{g} /$ day) & 50 & $60^{h}$ & $31,0-65,6^{i}$ \\
\hline Copper (mg/day) & 1,4 & Unknown ${ }^{\mathrm{j}}$ & $1,15-2,07^{\mathrm{k}}$ \\
\hline Zinc (mg/day) & 11,3 & Unknown' & $8,0-14,0^{m}$ \\
\hline
\end{tabular}

a RIVM, Inname vitamine A, vitamine D, foliumzuur, seleen, koper, zink, (2012-2016), available at https://wateetnederland.nl/resultaten/vitamines-en-mineralen/inname/.

b Moyersoen, I. et al., "Intake of fat-soluble vitamins in the Belgian population: Adequacy and contribution of foods, fortified foods and supplements", 9(8) Nutrients (2017), pp. 860 et sqq.

c EFSA NDA Panel, Scientific Opinion on Dietary Reference Values for Vitamin A, 13(3) EFSA Journal (2015).

d Moyersoen, "Intake of fat-soluble vitamins in the Belgian population: Adequacy and contribution of foods, fortified foods and supplements", supra note c.

e EFSA NDA Panel, Scientific Opinion on Dietary Reference Values for Vitamin D, 23 EFSA Journal (2016).

f HGR, Gezondheidsraad Voedingsaanbevelingen voor België, 2016 September 2016, Nr. 9285.

g EFSA NDA Panel, Scientific Opinion on Dietary Reference Values for Folate, 22 EFSA Journal (2014).

h Waegeneers, N., Thiry, C., De Temmerman, L., and Ruttens, A., "Predicted dietary intake of selenium by the general adult population in Belgium", 30(2) Food Additives and Contaminants - Part A Chemistry, Analysis, Control, Exposure and Risk Assessment (2013), pp. 278 et sqq.

i Panel, E., and Nda, A., Scientific Opinion on Dietary Reference Values for Selenium, 12(10) EFSA Journal (2014).

j EFSA, Overview on Tolerable Upper Intake Levels as derived by the Scientific Committee on Food (SCF) and the EFSA Panel on Dietetic Products, Nutrition and Allergies (NDA), supra note X.

k Panel, E., and Nda, A., Scientific Opinion on Dietary Reference Values for Copper, 13(10) EFSA Journal (2015).

I EFSA NDA Panel, Scientific Opinion on Dietary Reference Values for Zinc, 12(10) EFSA Journal, (2014), 76.

m Koninklijk Besluit van 3 Maart 1992 betreffende het in de handel brengen van nutriënten en van voedingsmiddelen waaraan nutriënten werden toegevoegd (B.S. 31.X.2017), 2017. 